\title{
Correction to: An integrated MVDR beamformer for speech enhancement using a local microphone array and external microphones
}

Randall Ali, Toon van Waterschoot and Marc Moonen

\section{Correction to: EURASIP J. Audio Speech Music} Process. (2021) 2021:10

https://doi.org/10.1186/s13636-020-00192-2

Following publication of the original article [1], an error was identified in the readability of eq. 45 , which should be read as below:

$$
\underline{\mathbf{w}}_{\mathrm{int}}=g_{a p}(\alpha, \beta) \widetilde{\mathbf{w}}_{\mathrm{mvdr}}+g_{d d}(\alpha, \beta) \hat{\mathbf{w}}_{\mathrm{mvdr}}
$$

Furthermore, a symbol on the left of eq. 21 has been changed.

The correct equation should be read as below:

$$
\underline{\mathbf{w}}_{\mathrm{mvdr}}=\frac{\underline{\mathbf{h}}}{\underline{\mathbf{h}}^{H} \underline{\mathbf{h}}}
$$

The original article has been corrected.
Published online: 06 April 2021

\section{Reference}

1. R. Ali et al., An integrated MVDR beamformer for speech enhancement using a local microphone array and external microphones. EURASIP J. Audio Speech Music Process. 2021, 10 (2021). https://doi.org/10.1186/s13636-02000192-2

* Correspondence: randall.ali@esat.kuleuven.be

KU Leuven, Department of Electrical Engineering (ESAT), STADIUS Center for Dynamical Systems, Signal Processing, and Data Analytics, Kasteelpark, Arenberg 10, 3001 Leuven, Belgium

\section{Springer Open}

(c) The Author(s). 2021 Open Access This article is licensed under a Creative Commons Attribution 4.0 International License, which permits use, sharing, adaptation, distribution and reproduction in any medium or format, as long as you give appropriate credit to the original author(s) and the source, provide a link to the Creative Commons licence, and indicate if changes were made. The images or other third party material in this article are included in the article's Creative Commons licence, unless indicated otherwise in a credit line to the material. If material is not included in the article's Creative Commons licence and your intended use is not permitted by statutory regulation or exceeds the permitted use, you will need to obtain permission directly from the copyright holder. To view a copy of this licence, visit http://creativecommons.org/licenses/by/4.0/. 